Putri, I.E. • Y.R. Suradinata $\cdot$ Kusumiyati

\title{
Pengaruh pemberian berbagar konsentrasi Benzyl Amino Purine (BAP) terhadap pertumbuhan tiga kultivar tanaman kamboja jepang (Adenium arabicum)
}

\author{
The effect of different concentrations of Benzyl Amino Purine (BAP) \\ on the growth three cambodian japan plant cultivars (Adenium \\ arabicum)
}

Diterima : 15 Februari 2017/Disetujui : 15 Maret 2017 / Dipublikasikan : 30 Maret 2017

CDepartment of Crop Science, Padjadjaran University

\begin{abstract}
Adenium arabicum is called as the dessert rose. This plants have caudex, which can be grow up if use benzyl amino purine (BAP) The aim of this experiment was to determine the effect of the interaction between the three Adenium arabicum with five concentrations of BAP was used and to obtain the cultivars tested that had the most growth either by treatment with various concentrations of BAP. The experiment was conducted from April up to July 2016 in the greenhouse Ciparanje, Faculty of Agriculture University of Padjadjaran, located at about 700 meters above sea level (masl). The experimental design used was a Randomize Block Designed factorial (RBD Factorial) consisted of two factors, the first factor was Yak saudi, Ra Chi Nee pan Dok $(\mathrm{RCN})$ and Thai Socotranum cultivar and the second factor was the concentrations of BAP consisted of 0 (part per million), $50 \mathrm{ppm}, 100 \mathrm{ppm}$, $150 \mathrm{ppm}$ and $200 \mathrm{ppm}$ were repeated 3 times. The results showed that there were interaction between cultivars and concentrations of BAP to the number of leaves and caudex. Thai Socotranum and Yak saudi growth higher with plant height, leaf area and accretion shoots than RCN but for caudex Thai Socotranum and RCN cultivars shows growth more better. BAP treatment with a concentrations of $150 \mathrm{ppm}$ and $200 \mathrm{ppm}$ resulted in higher growth for number of leaves, shoots as height and accretion shoot. In the leaf area concentration of $100 \mathrm{ppm}$ showed the best growth than others concentration. Thai Socotranum cultivars and BAP 150 ppm showed the best treatment.
\end{abstract}

Dikomunikasikan oleh Syariful Mubarok

Putri I.E $^{1} \cdot$ Y.R. Suradinata ${ }^{2} \cdot$ Kusumiyati $^{2}$

1) Alumni Program Studi Agroteknologi Faperta Unpad

2) Staf pengajar Departemen Budidaya Pertanian, Unpad

Korespondensi: neputrie@gmail.com
Keywords : Adenium arabicum - BAP · Caudex • Concentration $\cdot$ Cytokines

Sari Kamboja Jepang (Adenium arabicum) disebut sebagai mawar gurun. Tanaman ini memiliki bonggol yang dapat diperbesar dengan bantuan benzil amino purine (BAP). Tujuan dilakukannya penelitian ini adalah untuk mengetahui pengaruh interaksi antara tiga kultivar Kamboja Jepang dengan lima konsentrasi BAP yang digunakan dan untuk memperoleh kultivar diuji yang memiliki pertumbuhan paling baik dengan perlakuan berbagai konsentrasi BAP. Penelitian dilakukan dari bulan April sampai Juli 2016 di rumah kaca Ciparanje Fakultas Pertanian Univesitas Padjadjaran, dengan ketinggian tempat 700 meter di atas permukaan laut (mdpl). Percobaan dilakukan dengan Rancangan Acak Kelompok Faktorial (RAK Faktorial) yang terdiri atas dua faktor, faktor pertama yaitu kultivar Yak saudi, Ra Chi Nee Pan Dok (RCN) dan Thai Socotranum dan faktor kedua yaitu konsentrasi BAP terdiri atas 0 part per million (ppm), 50 ppm, 100 ppm, 150 ppm dan 200 ppm yang diulang sebanyak 3 kali. Hasil penelitian menunjukkan bahwa terjadi interaksi antara kultivar dan konsentrasi BAP terhadap jumlah daun dan diameter bonggol. Kultivar Thai Socotranum dan Yak saudi menghasilkan pertumbuhan tanaman yang lebih tinggi dicirikan dengan peningkatan tinggi tanaman, luas daun dan tunas lateral yang lebih tinggi daripada RCN namun pada pertambahan bonggol tanaman kultivar Thai Socotranum dan RCN menunjukkan petumbuhan yang lebih baik. Perlakuan BAP dengan konsentrasi 150 ppm dan 200 ppm menghasilkan rata-rata pertumbuhan lebih tinggi dicirikan dari jumlah daun, tinggi tanaman dan tunas lateral. Pada rata-rata pertambahan luas 
daun konsentrasi 100 ppm menunjukkan pertumbuhan yang lebih baik daripada konsentrasi yang lainnya. Kultivar Thai Socotranum dan BAP 150 ppm menunjukkan hasil perlakuan terbaik.

Kata kunci : Adenium arabicum - BAP · Diameter bonggol $\cdot$ Konsentrasi $\cdot$ Sitokinin

\section{Pendahuluan}

Seiring dengan berkembangnya zaman, saat ini ketertarikan masyarakat terhadap tanaman hias semakin meningkat. Salah satu alasannya karena tanaman hias memiliki nilai estetika yang dapat memperindah tempat di dalam maupun di luar ruangan. Jumlah penggemar tanaman hias akan mengalami peningkatan yang berbanding lurus dengan meningkatnya status sosial, ilmu pengetahuan dan teknologi (Suryowinoto, 1997 dalam Ekosari, 2009). Data nilai ekspor tanaman hias Indonesia mengalami kenaikan selama rentang waktu tahun 2007 hingga 2011. Volume ekspor tertinggi berada pada tahun 2009 dengan total ekspor sebanyak 5.111 ton sedangkan untuk total pendapatan ekspor tertinggi terjadi pada 2011 sebesar 13.160.381 US\$. Nilai-nilai tersebut mengalami peningkatan jika dibandingkan dengan tahun 2007 yang hanya mencapai 4.621 ton dan pendapatan 6.899.222 US\$. Terjadi kenaikan sebesar 10,6\% dari volume ekspor 2007 ke 2009 sedangkan untuk pendapatan terjadi kenaikan sebanyak 90,7\% dari tahun 2007 ke tahun 2011 (Direktorat Jenderal Hortikultura, 2012).

Di Indonesia saat ini salah satu incaran para penggemar tanaman hias adalah Adenium atau yang juga dikenal sebagai Kamboja Jepang. Jenis Adenium yang banyak diminati adalah jenis Adenium arabicum. Tanaman ini bukan hanya memiliki bunga yang kompak dan indah tapi juga memiliki percabangan yang banyak. Tanaman Adenium arabicum ini juga dikenal karena memiliki daya tarik sebagai tanaman hias dengan bonggol yang besar, menarik dan indah (Beikram \& Andoko, 2004).

Bonggol tanaman Adenium adalah bagian akar yang terdapat di pangkal batang yang dapat membesar. Adenium arabicum berasal dari semenanjung Arab sebelah Barat dan Selatan, terutama daerah sekitar Arab Saudi dan Yaman. Tanaman ini mendapat julukan "The Rose of Desert", yang diartikan sebagai bunga mawar dari padang pasir (Arwida, 2008). Berbagai jenis kultivar tanaman Adenium arabicum yang dikembangkan di Indonesia, terdapat 3 kultivar yang paling banyak ditemui yaitu jenis Yak Saudi yang memiliki percabangan yang banyak, RCN yang memiliki pertumbuhan cepat dan Thai Socotranum yang memiliki bonggol yang besar (Arwida, 2008)..

Nilai estetika tanaman Adenium bertambah dengan menggunakan berbagai cara diantaranya penggunaan Zat Pengatur Tumbuh (ZPT). ZPT adalah senyawa organik yang dapat mendorong, mengatur atau menghambat proses fisiologis tanaman (Abidin, 1990). Pemakaian konsentrasi yang tepat merupakan hal yang sangat penting. Salah satu usaha yang dilakukan untuk meningkatkan diameter bonggol Adenium adalah dengan memberikan zat pengatur tumbuh, yang dapat memengaruhi pertumbuhan Adenium terutama pertumbuhan akar dan batangnya. Hormon yang digunakan dapat berupa hormon sitokinin. Hormon sitokinin dapat diaplikasikan dalam upaya memperbesar bonggol tanaman, dengan semakin banyak sel yang membelah akan memperbesar volume organ tanaman. Sitokinin mempunyai kemampuan untuk memicu pembelahan sel (Salisbury \& Ross, 1995).

Hormon sitokinin dibutuhkan tanaman dalam jumlah yang sedikit. Berbagai jenis sitokinin yang sering dimanfaatkan, antara lain sitokinin jenis benzyl amino purine (BAP) karena harganya yang relatif murah juga efisiensinya yang tinggi (Yusnita, 2003). Pemberian BAP salah satunya dapat mempercepat laju pertumbuhan tanaman karena merangsang ujung tunas dari tanaman dan mengubahnya menjadi meristem aktif (Jauhari, 2008).

\section{Bahan dan Metode}

Percobaan dilakukan mulai Bulan April 2016 sampai Bulan Juni 2016 di rumah kaca Fakultas Pertanian Universitas Padjadjaran di Ciparanje, Jatinangor, Sumedang yang memiliki ketinggian yaitu 700 meter di atas permukaan laut. Metode yang digunakan adalah rancangan Rancangan Acak Kelompok (RAK) Faktorial. Faktor pertama adalah jenis kultivar (k) tanaman Adenium arabicum terdiri dari 3 taraf Yak Saudi, RCN dan Thai Socotranum sedangkan untuk faktor kedua adalah jumlah konsentrasi sitokinin BAP (s) yang digunakan terdiri dari 
lima taraf yaitu 0 ppm, 50 ppm, 100 ppm, 150 ppm dan $200 \mathrm{ppm}$. Total terdapat 15 perlakuan dengan tiga kali ulangan. Jika dijumlahkan terdapat 45 unit satuan percobaan. Pada masingmasing plot satuan unit percobaan terdapat dua tanaman sehingga untuk jumlah populasi secara keseluruhan adalah 90 tanaman. Pengaplikasian BAP dilakukan 6 kali dengan interval 2 minggu sesuai kalibrasi. Analisis statistik menggunakan SPSS 17. Pengaplikasian BAP dengan menggunakan handsprayer.

\section{Hasil dan Pembahasan}

Pada pengamatan penunjang didapatkan kondisi suhu harian rata-rata yaitu $26,03{ }^{\circ} \mathrm{C}, 26,31{ }^{\circ} \mathrm{C}$ dan $26,64{ }^{\circ} \mathrm{C}$ untuk Bulan April hingga Bulan Juni yang sesuai untuk pertanaman Adenium, kelembaban rata-rata harian dari Bulan April hingga Bulan Juni berturut-turut yaitu $71,73 \%$, 72,97\% dan $67,99 \%$ yang sesuai untuk pertumbuhan tanaman Adenium, inten-sitas cahaya rata-rata harian berkisar antara 24 watt.m-2, 28 watt. ${ }^{-2}$ dan 24 watt. $\mathrm{m}^{-2}$ di dalam rumah kaca sedangkan intensitas cahaya rata-rata harian di luar rumah kaca adalah 39 watt.m-2 49 watt. ${ }^{-2}$ dan 49 watt.m2 , intensitas kerusakan daun sebesar 23,63\% oleh tungau dan untuk intensitas kerusakan daun yang disebabkan kutu putih paling parah sebesar 1,6 ekor/daun dan intensitas serangan penyakit sebesar 1,11\% berupa penyakit virus kuning. $\mathrm{pH}$ selama penelitian berkisar antara 6,6-7,3dan terdapat beberapa perlakuan yang berbunga tampak paada Gambar 1 yaitu Thai Socotranum+ BAP 200 ppm dan Yak Saudi+BAP 0 ppm ulangan ke-3.

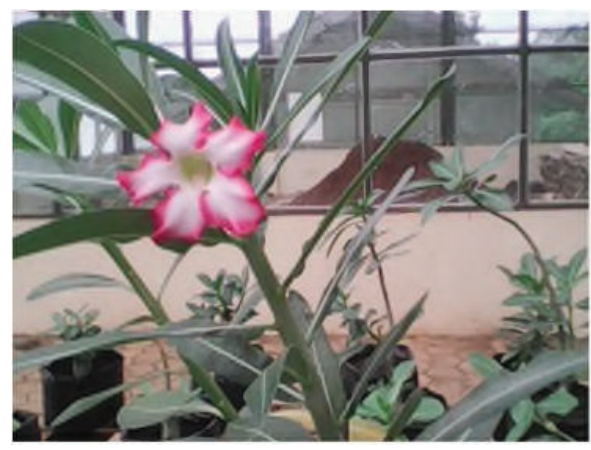

Gambar 1. Bunga Adenium arabicum

Pengamatan pada rata-rata pertambahan tinggi tanaman tidak terjadi interaksi antara kultivar dan konsentrasi BAP, namun tabel 1 menunjukkan perbedaan yang nyata pada 2 MSP dan 6 MSP terhadap rata-rata pertambahan tinggi tanaman pada tiga kultivar, sedangkan perlakuan konsentrasi BAP memberikan pengaruh yang nyata pada 8 MSP dan 10 MSP.

Pertumbuhan tanaman berbeda-beda, tergantung dari lingkungan sekitar tanaman tumbuh atau faktor yang berasal dari tanaman tersebut. Adaptasi Thai Socotranum terhadap apikasi BAP yang diberikan lebih tinggi sehingga langsung menunjukkan pertumbuhan yang berbeda nyata pada 2 MSP. Hal ini diakibatkan dari pola pertumbuhan Thai socotranum mengalami pola pertumbuhan sigmoid yang mengalami peningkatan di awal perlakuan lalu menurun pada akhir seperti terlihat pada Tabel 1. Pada pengamatan 6 MSP tampak RCN mengalami kenaikan pertumbuhan dibandingkan dengan kulitvar yang diujikan lainnya dan terdapat penurunan pada minggu-minggu berikutnya, pola pertumbuhan

Tabel 1. Pengaruh Konsentrasi BAP pada Kultivar Adenium arabicum terhadap Rata-Rata Pertambahan Tinggi Tanaman

\begin{tabular}{|c|c|c|c|c|c|c|}
\hline \multirow[t]{2}{*}{ Perlakuan } & \multicolumn{6}{|c|}{ Rata-Rata Pertambahan Tinggi Tanaman (cm) Minggu ke - } \\
\hline & 2 & 4 & 6 & 8 & 10 & 12 \\
\hline Yak Saudi & $1,35 \mathrm{a}$ & $1,84 \mathrm{a}$ & $3,35 \mathrm{~b}$ & $2,38 \mathrm{a}$ & $2,12 \mathrm{a}$ & $2,35 \mathrm{a}$ \\
\hline $\mathrm{RCN}$ & $1,64 \mathrm{ab}$ & $1,68 \mathrm{a}$ & $1,97 \mathrm{a}$ & $1,64 \mathrm{a}$ & $1,53 \mathrm{a}$ & $1,90 \mathrm{a}$ \\
\hline Thai Socotranum & $2,05 \mathrm{~b}$ & $1,45 \mathrm{a}$ & $1,52 \mathrm{a}$ & $2,63 \mathrm{a}$ & $1,78 \mathrm{a}$ & $1,75 \mathrm{a}$ \\
\hline BAP 0 ppm & $1,73 \mathrm{a}$ & $1,31 \mathrm{a}$ & $1,29 a$ & $1,87 \mathrm{ab}$ & $1,47 \mathrm{a}$ & $2,13 \mathrm{a}$ \\
\hline BAP 50 ppm & $1,27 \mathrm{a}$ & $1,43 \mathrm{a}$ & $2,28 \mathrm{a}$ & $2,02 \mathrm{ab}$ & $1,90 \mathrm{ab}$ & $2,28 \mathrm{a}$ \\
\hline BAP 100 ppm & $1,66 \mathrm{a}$ & $1,74 \mathrm{a}$ & $2,41 \mathrm{a}$ & $1,47 \mathrm{a}$ & $1,44 \mathrm{a}$ & $1,17 \mathrm{a}$ \\
\hline BAP 150 ppm & $1,27 \mathrm{a}$ & $1,77 \mathrm{a}$ & $2,62 \mathrm{a}$ & $2,24 a b$ & $2,68 \mathrm{~b}$ & $2,24 \mathrm{a}$ \\
\hline BAP 200 ppm & $2,09 a$ & $2,05 \mathrm{a}$ & $2,79 a$ & $3,48 \mathrm{~b}$ & $1,57 \mathrm{a}$ & $2,18 \mathrm{a}$ \\
\hline
\end{tabular}

Keterangan : Nilai rata-rata yang ditandai huruf yang sama pada kolom yang sama menunjukkan tidak berbeda nyata menurut uji jarak berganda Duncan pada taraf $5 \%$. 
sigomid juga ternyata dialami oleh $R C N$. Pola pertumbuhan sigmoid merupakan fase pertumbuhan awal pada fase vegetatif hingga fase tertentu yang mengakibatkan pertambahan sel tanaman dan akhirnya memasuki fase lambat (Gardner et al., 1991).

Pemberian BAP berbeda nyata pada 8 MSP dan 10 MSP, sedangkan tidak berbeda nyata pada 2, 4, 6 dan 12 MSP. Pada 8 MSP perlakuan BAP 200 ppm menunjukkan rata-rata pertam-bahan tinggi tanaman Adenium arabicum lebih tinggi dan terendah adalah perlakuan 100 ppm yang tidak berbeda nyata dengan perlakuan $0 \mathrm{ppm}, 50 \mathrm{ppm}$ dan 150 ppm. Pada 10 MSP pemberian BAP 150 ppm memberikan respon yang lebih tinggi dibandingkan dengan 4 perlakuan lainnya dan terendah yaitu $100 \mathrm{ppm}$ yang tidak berbeda nyata dengan perlakuan 0 ppm, 50 ppm dan 200 ppm. Pemberian BAP ternyata berpengaruh terhadap tinggi tanaman pada minggu-minggu tertentu, karena pembe-rian BAP akan berpengaruh pada pertumbuhan dan perkembangan batang tanaman tergantung dari konsentrasi, fase tanaman dan lingkungan di sekitar tanaman. Penambahan BAP pada tanaman Adenium memberikan pengaruh terhadap rata-rata pertambahan tinggi tanaman Adenium arabicum karena dalam pertumbuhan batang dan akar memerlukan sitokinin (Salisbury \& Ross, 1995).

Pada rata-rata pertambahan jumlah daun terdapat interaksi pada 4 MSP. Berdasarkan data pada Tabel 2 dapat dilihat bahwa perlakuan kultivar dan konsentrasi BAP menunjukkan bahwa kombinasi Yak Saudi dan 150 ppm memberikan rata-rata pertambahan jumlah daun terbanyak sedangkan interaksi kultivar dan BAP terendah untuk jumlah daun terdapat pada kombinasi perlakuan Yak saudi dan 0 ppm namun tidak memberikan pengaruh nyata dengan perlakuan yang lainnya. Kemampuan Tanaman Yak Saudi yang diaplikasikan BAP 150 ppm menghasilkan jumlah daun baru terbanyak. Hal ini menunjukkan bahwa dengan pemberian BAP 150 ppm membantu mempercepat jaringan meristem pada kultivar Yak Saudi.

Tabel 2. Interaksi Kultivar Tanaman Adenium arabicum dan Konsentrasi BAP terhadap RataRata Pertambahan Jumlah Daun pada 4 MSP

\begin{tabular}{|c|c|c|c|c|c|}
\hline \multirow{2}{*}{$\begin{array}{l}\text { Konsentrasi } \\
\text { Kultivar }\end{array}$} & \multicolumn{5}{|c|}{$\begin{array}{r}\text { Rata-Rata Pertambahan Jumlah Daun } \\
\text { (Helai) pada } 4 \text { MSP }\end{array}$} \\
\hline & $0 \mathrm{ppm}$ & 50 & 100 & 150 & 200 \\
\hline & & ppm & ppm & ppm & ppm \\
\hline \multirow[t]{2}{*}{ Yak Saudi } & $0,83 \mathrm{a}$ & $1,50 \mathrm{a}$ & $1,33 \mathrm{a}$ & $5,33 \mathrm{~b}$ & $1,00 \mathrm{a}$ \\
\hline & A & A & A & A & A \\
\hline \multirow[t]{2}{*}{$R C N$} & $1,33 \mathrm{a}$ & $1,83 \mathrm{a}$ & $1,33 \mathrm{a}$ & $1,00 \mathrm{a}$ & $1,67 \mathrm{a}$ \\
\hline & A & A & A & A & A \\
\hline Thai & $2,00 \mathrm{a}$ & $2,83 \mathrm{a}$ & $1,00 \mathrm{a}$ & $1,30 \mathrm{a}$ & $2,67 \mathrm{a}$ \\
\hline Socotranum & A & A & A & A & A \\
\hline
\end{tabular}

Hasil pengamatan telah diuji lanjut dengan uji lanjut Duncun pada taraf 5\%.

Keterangan : - Notasi huruf kapital dibaca horizontal membandingkan konsentrasi BAP; Notasi huruf kecil diaca vertikal membandingkan jenis kultivar; - Angka yang diikuti huruf yang sama pada kolom yang sama tidak berbeda nyata secara statistik berdasarkan uji lanjut Duncan 5\%.

Tabel 3. Pengaruh Konsentrasi BAP pada Kultivar Adenium arabicum terhadap Rata-Rata Pertambahan Jumlah Daun Tanaman

\begin{tabular}{lccccc}
\hline \hline \multirow{2}{*}{ Perlakuan } & \multicolumn{5}{c}{ Rata-Rata Pertambahan Jumlah Daun (Helai) Minggu ke - } \\
\cline { 2 - 5 } & 2 & 6 & 8 & 10 & 12 \\
\hline Yak Saudi & $3,9 \mathrm{a}$ & $3,7 \mathrm{a}$ & $6,1 \mathrm{~b}$ & $8,5 \mathrm{a}$ & $1,73 \mathrm{ab}$ \\
RCN & $2,5 \mathrm{a}$ & $2,5 \mathrm{a}$ & $3,0 \mathrm{a}$ & $5,2 \mathrm{a}$ & $1,90 \mathrm{~b}$ \\
Thai Socotranum & $4,2 \mathrm{a}$ & $4,9 \mathrm{a}$ & $4,3 \mathrm{ab}$ & $7,9 \mathrm{a}$ & $1,15 \mathrm{a}$ \\
\hline BAP 0 ppm & $2,4 \mathrm{a}$ & $1,2 \mathrm{a}$ & $1,9 \mathrm{a}$ & $3,0 \mathrm{a}$ & $1,23 \mathrm{a}$ \\
BAP 50 ppm & $5,4 \mathrm{~b}$ & $4,1 \mathrm{a}$ & $3,7 \mathrm{ab}$ & $6,1 \mathrm{ab}$ & $1,32 \mathrm{a}$ \\
BAP 100 ppm & $3,8 \mathrm{ab}$ & $4,6 \mathrm{a}$ & $4,6 \mathrm{ab}$ & $6,6 \mathrm{ab}$ & $1,47 \mathrm{a}$ \\
BAP 150 ppm & $2,6 \mathrm{a}$ & $4,8 \mathrm{a}$ & $5,5 \mathrm{ab}$ & $10,7 \mathrm{~b}$ & $2,02 \mathrm{a}$ \\
BAP 200 ppm & $3,5 \mathrm{ab}$ & $3,6 \mathrm{a}$ & $6,7 \mathrm{~b}$ & $9,6 \mathrm{~b}$ & $1,94 \mathrm{a}$ \\
\hline \hline
\end{tabular}

Keterangan : Nilai rata-rata yang ditandai huruf yang sama pada kolom yang sama menunjukkan tidak berbeda nyata menurut uji jarak berganda Duncan pada taraf $5 \%$. 
Tabel 4. Pengaruh Konsentrasi BAP pada Kultivar Adenium arabicum terhadap Rata-Rata Pertambahan Luas Daun Tanaman

\begin{tabular}{llllllc}
\hline \hline & \multicolumn{7}{l}{ Rata-Rata Pertambahan Luas Daun $\left(\mathrm{mm}^{2}\right)$ Minggu ke - } \\
\cline { 2 - 6 } & $2 \mathrm{MSP}$ & $4 \mathrm{MSP}$ & $6 \mathrm{MSP}$ & $8 \mathrm{MSP}$ & $10 \mathrm{MSP}$ & $12 \mathrm{MSP}$ \\
\hline Yak Saudi & $2,97 \mathrm{a}$ & $1,98 \mathrm{a}$ & $2,17 \mathrm{a}$ & $6,24 \mathrm{~b}$ & $3,93 \mathrm{~b}$ & $2,84 \mathrm{~b}$ \\
RCN & $2,95 \mathrm{a}$ & $2,96 \mathrm{a}$ & $1,94 \mathrm{a}$ & $2,75 \mathrm{a}$ & $2,17 \mathrm{a}$ & $1,92 \mathrm{a}$ \\
Thai Socotranum & $3,70 \mathrm{a}$ & $3,66 \mathrm{a}$ & $2,06 \mathrm{a}$ & $2,93 \mathrm{a}$ & $2,45 \mathrm{a}$ & $2,17 \mathrm{ab}$ \\
\hline BAP 0 ppm & $2,88 \mathrm{a}$ & $3,03 \mathrm{a}$ & $2,44 \mathrm{a}$ & $2,97 \mathrm{ab}$ & $1,87 \mathrm{a}$ & $1,85 \mathrm{a}$ \\
BAP 50 ppm & $4,39 \mathrm{a}$ & $3,79 \mathrm{a}$ & $2,34 \mathrm{a}$ & $5,02 \mathrm{ab}$ & $3,30 \mathrm{ab}$ & $2,36 \mathrm{a}$ \\
BAP 100 ppm & $2,53 \mathrm{a}$ & $2,36 \mathrm{a}$ & $1,48 \mathrm{a}$ & $5,33 \mathrm{~b}$ & $3,70 \mathrm{~b}$ & $2,48 \mathrm{a}$ \\
BAP 150 ppm & $2,99 \mathrm{a}$ & $2,67 \mathrm{a}$ & $2,36 \mathrm{a}$ & $4,40 \mathrm{ab}$ & $3,35 \mathrm{ab}$ & $2,86 \mathrm{a}$ \\
BAP 200 ppm & $3,31 \mathrm{a}$ & $2,47 \mathrm{a}$ & $1,67 \mathrm{a}$ & $2,13 \mathrm{a}$ & $2,03 \mathrm{ab}$ & $2,00 \mathrm{a}$ \\
\hline \hline
\end{tabular}

Keterangan :Nilai rata-rata yang ditandai huruf yang sama pada kolom yang sama menunjukkan tidak berbeda nyata menurut uji jarak berganda Duncan pada taraf $5 \%$.

Pada Tabel 3 untuk rata-rata pertambahan jumlah daun perlakuan kultivar terdapat perbedaan nyata terhadap rata-rata pertambahan jumlah daun tanaman Adenium arabicum untuk $8 \mathrm{MSP}$, sedangkan perlakuan konsentrasi BAP memberikan pengaruh nyata untuk 2 MSP, 8 MSP dan 10 MSP. Pada 8 MSP kultivar yang diujikan menunjukkan perbedaan yang nyata, hal ini dikarenakan bahwa rata-rata pertumbuhan jumlah daun tanaman Adenium arabicum lebih banyak dipengaruhi oleh sifat genetis tanaman. Pertambahan jumlah daun dari suatu tanaman juga bisa disebabkan kemampuan tanaman dalam membentuk daun baru tergantung dari berbagai faktor, diantaranya ketersediaan unsur hara yang tersedia dan genetis tanaman tersebut (Fauziyah, 2014).

Pada 2 MSP konsentrasi 50 ppm memberikan rata-rata pertambahan jumlah daun lebih banyak namun tidak berbeda dengan 100 ppm dan 200 ppm. Pada 2 MSP pengaplikasian BAP langsung memberikan hasil yang berbeda nyata terhadap rata-rata pertambahan jumlah daun tanaman Adenium arabicum. Pemberian konsentrasi BAP menghasilkan respon yang berbeda-beda,tergantung konsentrasi, metode aplikasi yang digunakan, waktu aplikasi dan kombinasi ZPT yang dipakai (Fahmi, 2014).

Pada 8 MSP rata-rata pertambahan jumlah daun tanaman Adenium arabicum lebih banyak untuk perlakuan 200 ppm dan terendah adalah perlakuan 0 ppm namun perlakuan dengan pertambahan tertinggi tidak berbeda nyata dengan perlakuan 50 ppm, 100 ppm dan 150 ppm. Pada 10 MSP pertambahan jumlah daun tertinggi adalah BAP 150 ppm yang tidak berbeda nyata dengan perlakuan lainnya kecuali perlakuan BAP 0 ppm. Perlakuan 0 ppm dari setiap 2 minggu pengamatan tidak menun-jukkan perbedaan yang nyata, hal ini sesuai dengan penyataan Untung
(2008) yang menyebutkan jika konsentrasi yang diberikan terlalu rendah pengaruhnya tidak akan ada, sebaliknya jika diaplikasikan secara berlebih, pertumbuhan tanaman justru terhambat atau bahkan mati sama sekali, dengan jumlah daun yang banyak diharapkan dapat meningkatkan hasil fotosintat tanaman yang digunakan untuk tumbuh dan berkembang.

Banyaknya rata-rata pertambahan jumlah daun tanaman Adenium arabicum berpengaruh terhadap rata-rata pertambahan parameter tinggi tanaman Adenium arabicum yang terdapat pada 8 MSP dan 10 MSP dapat dilihat pada Tabel 2, membuktikan bahwa jumlah daun berpengaruh dengan banyaknya hasil fotosintat yang dihasilkan karena daun merupakan tempat terjadinya proses fotosintesis.

Luas daun menjadi salah satu indikator pertumbuhan yang penting. Luas daun akan memengaruhi hasil fotosintesis yang diperoleh. Data pada Tabel 4 menunjukkan kultivar berpengaruh dalam meningkatkan rata-rata pertambahan luas daun 8 MSP, 10 MSP dan 12 MSP.

Pada 8 MSP kultivar Yak Saudi berpengaruh nyata terhadap rata-rata luas daun dibandingkan dengan perlakuan lainnya. Perlakuan Yak Saudi menjadi kultivar yang berbeda nyata dengan perlakuan RCN dan Thai Socotranum pada 10 MSP. Perbedaan rata-rata pertambahan luas daun menunjukkan bahwa respon tanaman yang berbeda tergantung dari sifat genetis dan lingkungan sekitar tanaman. Rata-rata pertambahan luas daun tanaman Adenium arabicum pada minggu-minggu awal belum menunjukan perbedaan yang nyata karena pertumbuhan di awal setelah perlakuan memperlihatkan bahwa respon tanaman lambat.

Pada 10 MSP aplikasi 100 ppm menghasilkan rata-rata pertambahan luas daun tanaman 
Adenium arabicum terbaik dibandingkan 0 ppm. BAP 100 ppm menunjukkan rata-rata pertambahan luas daun tanaman Adenium arabicum yang optimal untuk luas daun. Hal ini sesuai dengan penelitian yang telah dilakukan oleh Karismawati tahun 2006 menyatakan bahwa pemberian hormon sitokinin berupa kinetin 100 ppm memberikan pengaruh berupa peningkatan luas daun tanaman Adenium, diasumsikan bahwa pemberian BAP 100 ppm akan merangsang primordia daun dan akan mempercepat pembelahan sel untuk berkembang dan memperluas area daun (Jauhari, 2008).

Berdasarkan hasil uji statistik menunjukkan terdapat interaksi antara perlakuan kultivar dengan BAP terhadap rata-rata pertambahan diameter bonggol tanaman Adenium arabicum pada 10 MSP. Berdasarkan data pada Tabel 5.

Pada Tabel 5 dapat dilihat bahwa perlakuan terkecil adalah Thai Socotranum+100 ppm yang tidak berbeda nyata dengan perlakuan lainnya kecuali Yak Saudi+50 ppm. Kombinasi perlakuan Yak Saudi+50 ppm berbeda nyata dapat disebabkan karena genetis tanaman, konsentrasi BAP atau faktor lingkungan.

Tabel 6 pengaruh mandiri hasil analisis ragam menunjukkan bahwa terdapat perbedaan nyata terhadap pertambahan diameter bonggol tanaman pada kultivar yang diuji pada 12 MSP.

Kultivar Thai Socotranum menunjukkan pertambahan diameter bonggol lebih baik daripada kultivar Yak saudi walaupun perlakuan pada Thai Socotranum tidak berbeda nyata dengan kultivar RCN. Kultivar Thai Socotranum menunjukkan rata-rata pertambahan bonggol tanaman Adenium arabicum yang lebih besar, ini sesuai dengan karakteristik bonggolnya yang lebih unggul ketimbang kultivar RCN dan Thai Socotranum. Karakteristik kultivar Thai Socotranum memang memiliki bonggol yang besar.

Tabel 5. Interaksi Kultivar Tanaman Adenium arabicum dan Konsentrasi BAP terhadap Rata-Rata Pertambahan Diameter Bonggol pada 10 MSP

\begin{tabular}{lccccc}
\hline \hline \multirow{2}{*}{ Konsentrasi } & \multicolumn{5}{c}{ Rata-Rata Pertambahan Diameter Bonggol $\left(\mathrm{mm}^{2}\right)$} \\
\cline { 2 - 6 } Kultivar & $0 \mathrm{ppm}$ & $50 \mathrm{ppm}$ & $100 \mathrm{ppm}$ & $150 \mathrm{ppm}$ & $200 \mathrm{ppm}$ \\
\hline Yak Saudi & $1,02 \mathrm{a}$ & $2,44 \mathrm{a}$ & $2,03 \mathrm{a}$ & $1,33 \mathrm{a}$ & $1,44 \mathrm{a}$ \\
\multirow{2}{*}{ RCN } & $\mathrm{A}$ & $\mathrm{B}$ & $\mathrm{AB}$ & $\mathrm{AB}$ & $\mathrm{AB}$ \\
& $0,90 \mathrm{a}$ & $0,95 \mathrm{a}$ & $3,29 \mathrm{a}$ & $3,29 \mathrm{a}$ & $1,00 \mathrm{a}$ \\
Thai Socotranum & $\mathrm{A}$ & $\mathrm{A}$ & $\mathrm{A}$ & $\mathrm{A}$ & $\mathrm{A}$ \\
& $2,35 \mathrm{a}$ & $2,53 \mathrm{a}$ & $0,64 \mathrm{a}$ & $0,83 \mathrm{a}$ & $1,35 \mathrm{a}$ \\
& $\mathrm{A}$ & $\mathrm{A}$ & $\mathrm{A}$ & $\mathrm{A}$ & $\mathrm{A}$ \\
\hline \hline
\end{tabular}

Hasil pengamatan telah diuji lanjut dengan uji lanjut Duncun pada taraf $5 \%$.

Tabel 6. Pengaruh Konsentrasi BAP pada Kultivar Adenium arabicum terhadap Rata-Rata Pertambahan Diameter Bonggol Tanaman

\begin{tabular}{lccccc}
\hline \hline & \multicolumn{5}{c}{ Rata-Rata Pertambahan Diameter Bonggol (mm) Minggu ke- } \\
\cline { 2 - 5 } Perlakuan & $2 \mathrm{MSP}$ & $4 \mathrm{MSP}$ & $6 \mathrm{MSP}$ & $8 \mathrm{MSP}$ & $12 \mathrm{MSP}$ \\
\hline Yak Saudi & $1,00 \mathrm{a}$ & $1,84 \mathrm{a}$ & $2,06 \mathrm{a}$ & $1,08 \mathrm{a}$ & $1,27 \mathrm{a}$ \\
RCN & $0,96 \mathrm{a}$ & $1,33 \mathrm{a}$ & $1,14 \mathrm{a}$ & $1,10 \mathrm{a}$ & $1,60 \mathrm{ab}$ \\
Thai Socotranum & $1,25 \mathrm{a}$ & $1,55 \mathrm{a}$ & $1,91 \mathrm{a}$ & $1,74 \mathrm{a}$ & $2,34 \mathrm{~b}$ \\
\hline BAP 0 ppm & $1,14 \mathrm{a}$ & $1,50 \mathrm{a}$ & $1,69 \mathrm{a}$ & $1,34 \mathrm{a}$ & $1,66 \mathrm{a}$ \\
BAP 50 ppm & $1,06 \mathrm{a}$ & $1,69 \mathrm{a}$ & $1,91 \mathrm{a}$ & $0,90 \mathrm{a}$ & $1,60 \mathrm{a}$ \\
BAP 100 ppm & $0,86 \mathrm{a}$ & $1,80 \mathrm{a}$ & $1,50 \mathrm{a}$ & $1,00 \mathrm{a}$ & $1,55 \mathrm{a}$ \\
BAP 150 ppm & $1,10 \mathrm{a}$ & $1,53 \mathrm{a}$ & $1,61 \mathrm{a}$ & $1,60 \mathrm{a}$ & $1,77 \mathrm{a}$ \\
BAP 200 ppm & $1,19 \mathrm{a}$ & $1,35 \mathrm{a}$ & $1,81 \mathrm{a}$ & $1,68 \mathrm{a}$ & $2,10 \mathrm{a}$ \\
\hline \hline
\end{tabular}

Keterangan : Nilai rata-rata yang ditandai huruf yang sama pada kolom yang sama menunjukkan tidak berbeda nyata menurut uji jarak berganda Duncan pada taraf $5 \%$. 
Tabel 7. Pengaruh Konsentrasi BAP pada Kultivar BAP terhadap Rata-Rata Pertambahan Tunas Lateral Tanaman Adenium arabicum

\begin{tabular}{lcccccc}
\hline \hline Perlakuan & \multicolumn{5}{c}{ Rata-Rata Pertambahan Tunas Lateral Minggu ke- } \\
\cline { 2 - 6 } & $2 \mathrm{MSP}$ & $4 \mathrm{MSP}$ & $6 \mathrm{MSP}$ & $8 \mathrm{MSP}$ & $10 \mathrm{MSP}$ & $12 \mathrm{MSP}$ \\
\hline Yak Saudi & $0,97 \mathrm{~b}$ & $0,78 \mathrm{a}$ & $0,77 \mathrm{a}$ & $0,80 \mathrm{a}$ & $1,05 \mathrm{a}$ & $1,02 \mathrm{a}$ \\
RCN & $0,76 \mathrm{a}$ & $0,80 \mathrm{a}$ & $0,81 \mathrm{a}$ & $0,78 \mathrm{a}$ & $0,86 \mathrm{a}$ & $0,83 \mathrm{a}$ \\
Thai Socotranum & $0,82 \mathrm{ab}$ & $0,91 \mathrm{a}$ & $0,76 \mathrm{a}$ & $0,83 \mathrm{a}$ & $0,81 \mathrm{a}$ & $0,81 \mathrm{a}$ \\
\hline BAP 0 ppm & $0,80 \mathrm{a}$ & $0,74 \mathrm{a}$ & $0,74 \mathrm{a}$ & $0,74 \mathrm{a}$ & $0,76 \mathrm{a}$ & $0,82 \mathrm{a}$ \\
BAP 50 ppm & $0,85 \mathrm{a}$ & $0,84 \mathrm{ab}$ & $0,78 \mathrm{a}$ & $0,83 \mathrm{a}$ & $0,86 \mathrm{a}$ & $0,86 \mathrm{a}$ \\
BAP 100 ppm & $0,86 \mathrm{a}$ & $0,80 \mathrm{ab}$ & $0,77 \mathrm{a}$ & $0,77 \mathrm{a}$ & $0,79 \mathrm{a}$ & $0,99 \mathrm{a}$ \\
BAP 150 ppm & $0,89 \mathrm{a}$ & $0,98 \mathrm{~b}$ & $0,85 \mathrm{a}$ & $0,86 \mathrm{a}$ & $0,90 \mathrm{ab}$ & $0,87 \mathrm{a}$ \\
BAP 200 ppm & $0,86 \mathrm{a}$ & $0,80 \mathrm{ab}$ & $0,77 \mathrm{a}$ & $0,83 \mathrm{a}$ & $1,23 \mathrm{~b}$ & $0,89 \mathrm{a}$ \\
\hline \hline
\end{tabular}

Keterangan : Nilai rata-rata yang ditandai huruf yang sama pada kolom yang sama menunjukkan tidak berbeda nyata menurut uji jarak berganda Duncan pada taraf $5 \%$.

Pada perlakuan mandiri aplikasi BAP menunjukkan bahwa perlakuan berbagai konsentrasi BAP tidak memberikan perbedaan yang nyata antara satu perlakuan dengan perlakuan yang lainnya. Pengaplikasian BAP dengan berbagai konsentrasi yang ada belum maksimal terhadap rata-rata pertambahan diameter bonggol tanaman Adenium arabicum. Kepekaan tanaman terhadap pemberian ZPT berbeda-beda. Keefektifan ZPT akan berbedabeda tergantung dari kondisi lingkungan yang ada, dosis yang tepat dan fase pertumbuhan yang tepat (Manurung dan Bangun, 1982).

Pertambahan tunas lateral menunjukkan pertumbuhan yang cepat pada 2 MSP sudah terdapat perbedaan pada perlakuan yang diujikan. Organ-organ tanaman akan dibentuk selama proses tumbuh dan berkembang.

Pengaplikasian konsentrasi BAP berpengaruh nyata pada 4 MSP dan 10 MSP namun tidak berbeda nyata pada 2 MSP, 6 MSP, 8 MSP dan 12 MSP. Pada 4 MSP pertambahan diameter terbesar adalah pada perlakuan BAP 150 ppm yang berbeda nyata dengan BAP 0 ppm namun tidak berbeda nyata dengan perlakuan lainnnya. Pada 10 MSP pertumbuhan tunas lateral terbaik adalah BAP 200 ppm yang tidak berbeda nyata dengan BAP 150 ppm tapi berbeda nyata dengan perlakuan yang diujikan lainnnya. Salah satu fungsi BAP adalah dapat menurunkan dominasi apikal yang bisa menyebabkan tunas samping akan tumbuh. Dominasi apikal dapat diturunkan dengan pemberian BAP yang berdampak pada pertumbuhan agar mengarah ke samping dan memungkinkan tunas-tunas lateral untuk dapat terus tumbuh dan berkembang (Abidin, 1983).

Pertambahan tunas lateral tertinggi terjadi pada konsentrasi-konsentrasi tinggi. Menurut
Balamani dan Poovaiah (1985) dalam Setyaningrum (2012) menyatakan bahwa dengan bertambah tingginya konsentrasi sitokinin akan menyebabkan tunas akan dengan lebih cepat dan membentuk lebih banyak cabang. Cabang yang banyak sangat diharapkan pada pertumbuhan dan perkembangan Adenium. Bentuk Adenium lebih menarik dan bernilai tinggi jika tanaman tersebut memiliki percabangan dan bentuk bonggol yang besar.

\section{Kesimpulan}

Terdapat hubungan yang saling memengaruhi antara konsentrasi BAP dan kultivar terhadap 2 parameter pengamatan, yaitu pertambahan jumlah daun pada 4 MSP dan pertambahan diameter bonggol pada 10 MSP. Konsentrasi BAP terbaik yang diberikan adalah 150 ppm dan kultivar terbaik yang telah diujikan adalah Thai Socotranum.

\section{Ucapan Terıma Kasih}

Terimakasih kepada berbagai pihak yang telah membantu selama penelitian ini.

\section{Daftar Pustaka}

Abidin, Z. 1990. Dasar-Dasar Pengetahuan Tentang Zat Pengatur Tumbuh. Bandung: Angkasa. 85 hal.

Arwida, S. 2008. Adenium arabicum Si Bonggol Eksotik. Jakarta: Gramedia Pustaka Utama. 96 hal. 
Beikram dan A. Andoko. 2004. Mempercantik Penampilan Adenium. Jakarta: Agromedia Pustaka.

Direktorat Jenderal Hortikultura. 2012. Data Produksi Tanaman Hias di Indonesia. www.hortikultura.pertanian.go.id. Diakses pada 20 Januari 2016.

Ekosari, A. 2009. Pengaruh GA3 dan IAA terhadap Pembesaran Bonggol Adenium (Adenium obesum). Skripsi. Surakarta: Fakultas Pertanian Universitas Sebelas Maret.

Fahmi, Z. I. 2014. Kajian Pengaruh Pemberian Sitokinin Terhadap Pertumbuhan Tanaman. Surabaya: Balai Besar Perbenihan dan Proteksi Tanaman Perkebunan. Http://www.ditjenbun.go.id. Diakses pada tanggal 10 Desember 2015.

Fauziah, R. 2014. Pengaruh Jumlah Batang Produksi terhadap Pertumbuhan, Hasil dan Kualitas Hasil Tomat CV. Marta 9 pada Berbagai Sistem Budidaya dalam Rumah Plastik di Jatinangor. Skripsi. Jatinangor: Fakultas Pertanian Universitas Padjadjaran. (Tidak dipublikasikan)

Gardner, F. P., Peace, R. B., dan Mitchell, R. B. 1991. Fisiologi Tanaman Budidaya. Depok: Universitas Indonesia Press.

Jauhari, R. 2008. Kajian Jenis Media Tanam dan Konsentrasi BAP (benzyl amino purine)
Terhadap Pertumbuhan Bibit Jambu Mete (Anacardium occidentale L). Tesis. Surakarta: Fakultas Pertanian Universitas Sebelas Maret.

Karismawati, D. 2006. Pengaruh Komposisi Media Tanam dan Macam Zat Pengatur Tumbuh Terhadap Nilai Estetika Bonggol Stek Adenium (Adenium SP). Surakarta: Fakultas Pertanian Universitas Sebelas Maret.

Manurung, S. O. F. Muhadjir dan P. Bangun. 1982. Status dan Potensi Hormon Pengatur Tumbuh pada Padi. Dama Makalah dan Hasil Penelitian Padi. Risalah Lokakarya Penelitian Padi. Puslitbang. Bogor.

Salisbury dan Ross. 1995. Fisiologi Tumbuhan Jilid 1. Bandung: Institut Teknologi Bandung. 241 hal.

Setyaningrum, F. 2012. Pengaruh Konsentrasi BAP terhadap Pertumbuhan Awal Entres Tiga Varietas Durian (Durio zibethius murr.) Pada Perbanyakan Vegetatif Okulasi. Skirpsi. Surakarta: Fakultas Pertanian Universitas Sebelas Maret.

Untung, O. 2008. Agar Tanaman Buah Berbuah Diluar Musim. Jakarta: Penebar Swadaya.

Yusnita. 2003. Kultur Jaringan: Cara Memperbanyak Tanaman Secara Efisien. Jakarta: Agromedia Pustaka. 105 Hal. 